\title{
CO-WORKING SPACE SEBAGAI SOLUSI KEBUTUHAN RUANG KERJA BERDASARKAN KARAKTERISTIK STARTUP KREATIF
}

\author{
Refyanti Dwi Pramedesty, Djoko Murdowo, Irwan Sudarisman, \\ dan Andreas D. Handoyo \\ Program Studi Desain Interior Universitas Telkom \\ refydwip@student.telkomuniversity.ac.id
}

\begin{abstract}
Abstrak: Startup kreatif saat ini berkembang pesat di Indonesia, begitu juga di kota Bandung. Karakteristik pengguna utamanya dari sektor startup kreatif mempunyai keunikan dan preferensi ruang yang dapat mengembangkan ide-ide segar dan baru. Karakteristik pengguna akan memengaruhi rancangan desain interior khususnya dalam karakteristik desain. Penelitian ini akan menganalisa keterkaitan rancangan ruang yang dapat mewadahi pengguna dengan karakteristik startup kreatif dan bagaimana menghadirkan desain interior yang dapat menstimuli dan menciptakan ide-ide kreatif bagi pengguna. Metode penelitian yang digunakan adalah penelitian kualitatif, dengan melakukan pengamatan lapangan serta penyebaran questionnaire. Penelitian ini mempergunakan sampel pengguna co-working space di Bandung, serta startup kreatif yang bergerak dalam 5 bidang dominan di Bandung. Hasil penelitian menunjukkan ruang yang dibutuhkan berupa co-working space dengan preferensi pada elemen interior.
\end{abstract}

Kata kunci: startup kreatif, co-working space, desain interior.

\begin{abstract}
Creative startup are currently growing rapidly in Indonesia, as well as in the city of Bandung. The main user characteristics of the creative startup have a unique and space preference that can develop fresh and new ideas. The characteristics of the user will affect the design especially on the character of the design. This paper will analyze the relevance of interior design that can accommodate users with creative startup characteristics and how to present interior design that can stimulate and create creative ideas for users. The research method is qualitative research, by doing field observation and questionnaire dissemination. This paper uses a sample of co-working space users in Bandung, as well as creative startup that stand in 5 dominant sector in Bandung. The results showed the required space of co-working space with preference on interior element.
\end{abstract}

Keywords: creative startup, co-working space, interior design.

\section{Pendahuluan}

\subsection{Latar Belakang}

Kondisi ekonomi saat ini telah memasuki era ekonomi gelombang ke-empat yang dikenal dengan nama era ekonomi kreatif. Diikuti dengan perkembangan startup di Indonesia yang setiap tahun, bahkan setiap bulan banyak bermunculan startup-startup baru di Indonesia. Startup merupakan industri rintisan dengan organisasi yang dirancang untuk menemukan model bisnis baru yang menghasilkan keuntungan besar (Blank, 2014). Sekarang ini setidaknya terdapat lebih dari 1.500 startup lokal yang berkancah di bidang Industri Kreatif yang ada di Indonesia.

Bandung yang menjadi Kota Kreatif Desain (UNESCO, 2015), memiliki penduduk lebih dari 2,5 juta jiwa telah menjadi pusat inovasi dan kreativitas, khususnya kreasi inisiatif yang didorong oleh kaum mudanya. Startup kreatif Bandung didominasi pada kegiatan yang berkaitan dengan desain komunikasi visual, aplikasi pengembangan permainan, desain interior, periklanan, film animasi dan video dan menjadikan Bandung sebagai sektor teratas dalam kegiatan ekonomi kreatif lokal. Bandung memiliki potensi besar dalam perkembangan startup kreatif di Indonesia. Namun banyak sekali startup yang gagal karena beberapa faktor antara lain kebutuhan pasar, konflik internal, kerjasama tim yang lemah serta pendanaan yang 
belum efisien, salah satunya sarana prasarana ruang untuk aktivitas yang relatif mahal dan infrastruktur yang sudah ada sekarang ini belum memadai khususnya fungsi yang sesuai dengan kebutuhan aktivitas dan karakteristik dari startup kreatif.

Untuk itu dibutuhkan ruang yang dapat mewadahi dan mengembangkan kreativitas para startup kreatif yang nyaman, sesuai kebutuhan dan mendukung suasana kolaboratif. Coworking space yang sedang tumbuh saat ini bisa menjadi alternatif. Penelitian ini berusaha mendalami seperti apakah co-working space yang cocok untuk para pegiat startup kreatif dan bagaimana suasana desain interior yang bisa menunjang suasana sesuai kebutuhan startup kreatif.

\subsection{Tantangan Startup Kreatif}

Startup merupakan perusahaan awal atau rintisan yang dibentuk untuk menciptakan produk inovatif, kreatif dan belum pernah dibuat sebelumnya. Ries (2011) berpendapat bahwa startup adalah sebuah organisasi yang diciptakan untuk membuat produk atau layanan baru dan inovatif dalam sebuah kondisi ketidakpastian yang tinggi di luar kemapanan dan ketidak pastian. Dalam industri startup dibutuhkan kreatifitas perusahaan maupun individu yang memiliki daya cipta, kemampuan penciptaan dan penemuan baru.

Di Indonesia sudah banyak startup yang yang berhasil dan tumbuh menjadi perusahaan yang sukses dengan pendapatan yang sangat besar dan masuk dalam kelompok bisnis tingkat dunia. Beberapa startup yang sukses seperti GO-Jek, Grab, Traveloka, Tokopedia, Bukalapak dan lain-lain. Namun tidak sedikit startup yang tumbang dan gagal sebelum masa launching, hampir 90\% startup yang diciptakan di dunia gagal (www.forbes.com). Hasil penelitian Mardi (2017) menunjukkan alasan gagalnya sebuah startup antara lain, tidak adanya konsumen yang tepat, tidak dapat menemukan model bisnis yang cocok, tingkat persaingan yang tinggi, tim yang kurang solid, ide dari bisnis itu sendiri, waktu yang kurang tepat dan tidak kalah pentingnya kebutuhan dana yang besar. Kebutuhan dana banyak digunakan untuk penyediaan sarana prasarana ruang yang kadang harus menyewa dengan biaya yang mahal.

\subsection{Karakteristik Startup Kreatif}

Karakter dapat dimaknai sebagai values (nilai-nilai), tingkah laku, watak, tabiat dan kepribadian seseorang, terbentuk melalui proses yang panjang, melalui tempaan lingkungan dan orang-orang yang berada di lingkungan tersebut. Dari sudut pandang etimologis, karakter berasal dari kata character yang berarti a distinctive differentiating mark, tanda atau sifat yang membedakan seseorang dengan orang lain (Syarbini, 2012, hlm. 13). Demikian juga yang terjadi dengan para pelaku startup kreatif yang dalam interaksinya mempunyai karakteristik tersendiri dan unik.

Profesor Oyyind L Martisen (2000) menyatakan karakteristik startup kreatif ini sebagai berikut :

Tabel 1. Karakteristik Startup Kreatif

\begin{tabular}{l|l}
\hline Orientasi Asosiatif & $\begin{array}{l}\text { imajinatif, menyenangkan, kaya ide, mampu berkomitmen, dan bisa membedakan } \\
\text { fakta dan fiksi. }\end{array}$ \\
\hline Keorisinilan & melawan aturan dan arus, untuk menghasilkan karya yang baru. \\
\hline Motivasi & memegang tujuan, inovatif, kuat saat menghadapi masalah sulit, dan berani tampil. \\
\hline Ambisi & $\begin{array}{l}\text { kemampuan mempengaruhi orang lain, menarik perhatian, dan keinginan untuk } \\
\text { diakui. }\end{array}$ \\
\hline
\end{tabular}




\begin{tabular}{l|l} 
Fleksibilitas & $\begin{array}{l}\text { kemampuan untuk melihat aspek yang berbeda dari masalah dan memunculkan } \\
\text { solusi yang optimal. }\end{array}$ \\
\hline Kestabilan Emosi Rendah & $\begin{array}{l}\text { kecenderungan untuk merasakan emosi negatif, moody, dan terkadang sering kurang } \\
\text { percaya diri. }\end{array}$ \\
\hline Keramahan Rendah & $\begin{array}{l}\text { cenderung individualis, tidak peduli, keras kepala, dan kerap mengkritik kesalahan } \\
\text { dan kekurangan ide orang lain. }\end{array}$
\end{tabular}

Sumber: Prof. Oyvind L. Martinsen (2000)

Dari acuan ini dapat digunakan sebagai panduan dalam mengobservasi karakteristik startup dikaitkan dengan kebutuhan lingkungan kerja, rancangan ruang dan sebagianya.

\subsection{Co-working Space}

Umumnya, co-working space dipahami sebagai sebuah lingkungan/ruang dimana beberapa profesi dapat bekerja dalam suatu area secara bersamaan baik dalam ruang privat ataupun ruang kerja terbuka (Metz \& Archuleta, n.d.; Septiani, Aldy, \& Firzal, 2017). Dalam aktivitas utamanya, co-working space tidak hanya merupakan ruang sewa yang dilengkapi fasilitas kerja tetapi juga berfungsi sosial bagi penggunanya untuk saling berinteraksi, bertukar informasi, dan berkolaborasi (Marcelina, Ardana, \& Yong, 2016; Soerjoatmodjo, 2015; Wijaya, Hasudungan, Sitindjak, \& Suryanata, 2017).

Berdasarkan tipe penggunanya, co-working space dapat dibagi menjadi tiga tipe. Pertama, coworking space bagi profesi khusus, yang digunakan oleh satu pelaku. Kedua, co-working space umum, dimana sering digunakan oleh freelancer dan perusahaan kecil. Desain dibuat dengan menyesuaikan kebutuhan dan karakter pengguna seperti unik, friendly, dan menyenangkan. Ketiga, co-working space khusus sebagai inkubator bisnis atau startup bisnis yang merupakan ruang kerja dengan manfaat tambahan tipe yang terakhir ini biasanya digunakan oleh para perusahaan aplikasi yang sedang merintis, sehingga dibutuhkan ruang khusus digital yang memfasilitasi untuk pengujian aplikasi yang sedang dibuat. Oleh karena itu, berbeda dengan ruang kantor pada umumnya, co-working space cenderung lebih cocok disebut sebagai ruang kerja yang terkurasi, artinya ruang tersebut sudah dipersiapkan untuk dapat mewadahi kegiatan-kegiatan kerja tertentu (Jakonen, Kivinen, Salovaara, \& Hirkman, 2017).

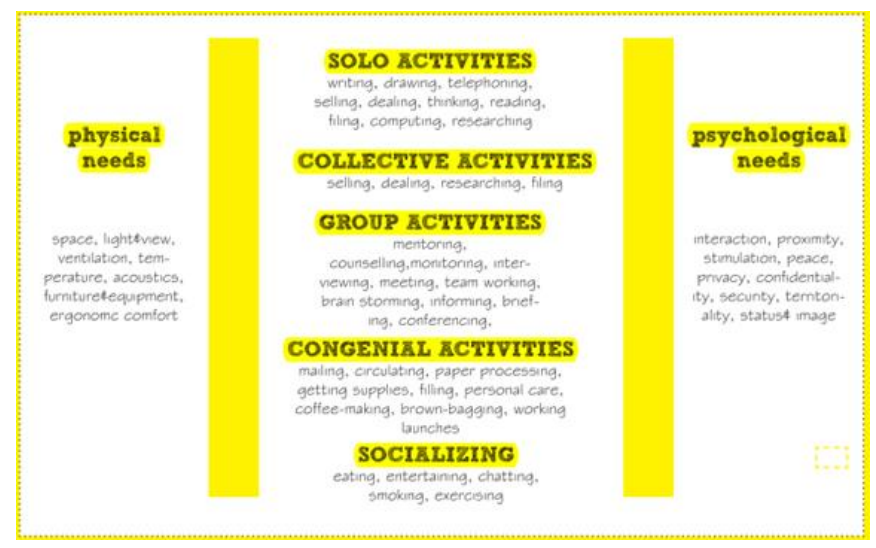

Gambar 1. Aktivitas Para Pengguna Co-working Space Sumber: Ergin (2013) 
Co-working space mempunyai standar ruang yang dapat mewadahi untuk kegiatan utama, adanya kebutuhan fisik interior yang dapat membuat nyaman pengguna terkait dengan pencahaayaan, penghawaan, suasana, suhu, furniture, dan kenyamanan egonomi. Di samping itu, area co-working space dilengkapi seringkali dengan berbagai fasilitas penunjang lain sehingga tidak sepenuhnya biaya operasional dibebankan pada biaya sewa pengunjung. Standar aktivitas dibagi menjadi beberapa golongan seperti aktivitas perorangan, kolektif, kelompok dan sosial. Tidak kalah pentingnya kebutuhan psikologis pengguna menjadi kebutuhan yang vital seperti interaksi, stimulai, privasi, keamanan, dll. Fasilitas yang ada cenderung tidak hanya memfasilitas generasi milenial sebagai pengguna dominan, tetapi juga mendorong perkembangan dan pertumbuhan dari bisnis startup itu sendiri. Dengan begitu, ruang co-working space dapat lebih optimal dan tepat sasaran bagi penggunanya (Merkel, 2015). Fasilitas yang menjadi keperluan bagi para penggiat startup khususnya dalam bidang kreatif dapat dikategorikan berdasarkan tipe areanya, antara lain :

Tabel 2. Analisa Kebutuhan Ruang Coworking Space

\begin{tabular}{|l|l|l|l|}
\hline \multicolumn{1}{|c|}{ No } & \multicolumn{1}{|c|}{ Kategori } & \multicolumn{1}{c|}{ Kebutuhan } & \multicolumn{1}{c|}{ Fasilitas } \\
\hline 1 & Area Utama & $\begin{array}{l}\text { 1. Area kerja individu } \\
\text { 2. Area kerja grup (saling kenal) } \\
\text { 3. Area kerja bersama (tidak saling } \\
\text { kenal) }\end{array}$ & Area co-working space \\
\hline 2 & Area Penunjang & $\begin{array}{l}\text { Area komersil, area bersosialisasi, } \\
\text { area sport }\end{array}$ & $\begin{array}{l}\text { Restoran, café, toko, fasilitas kesehatan, } \\
\text { ruang diskusi, area santai, perpustakaan, } \\
\text { auditorium, ruang arsip/ penitipan. }\end{array}$ \\
\hline 3 & Area Servis & Area staff, gudang & $\begin{array}{l}\text { Area kantor, janitor, toilet/ kamar mandi, } \\
\text { reseptionis., pantry }\end{array}$ \\
\hline
\end{tabular}

Sumber: (Bilandzic \& Foth, 2013; Brooke et al., 2014; Ergin, 2013; Russo \& Barnhill, n.d.)

\section{Metodologi Penelitian}

\subsection{Metode Penelitian}

Metode penelitian yang digunakan adalah penelitian kualitatif. Penelitian kualitatif adalah penelitian tentang riset yang bersifat deskriptif dan cenderung menggunakan analisis. Proses dan makna (perspektif subjek) lebih ditonjolkan dalam penelitian kualitatif. Landasan teori dimanfaatkan sebagai pemandu agar fokus penelitian sesuai dengan fakta di lapangan. Dengan melakukan pengamatan lapangan, penyebaran questionnaire dan wawancara. Lalu melakukan analisa keterkaitan elemen interior yang disesuaikan dengan karakteristik dan kebutuhan startup kreatif. Penelitian ini juga mempergunakan sampel pengguna co-working space di Bandung, serta startup kreatif yang bergerak dalam lima bidang dominan di Bandung.

\subsection{Metode Pengumpulan Data dan Analisa}

Dalam pengumpulan data, tahapan-tahapan yang dilakukan adalah sebagai berikut:

1. Menyebarkan questionnaire kepada startup kreatif yang bekerja di sebelas co-working space di Bandung untuk mengetahui sektor dominan di Bandung berdasarkan bidang pekerjaan startup kreatif pengguna co-working space di Bandung. 
2. Melakukan wawancara atau tanya jawab berkaitan dengan kebutuhan penelitian kepada startup kreatif yang bekerja pada lima sektor dominan di Bandung. Data yang dibutuhkan adalah alur aktivitas dan kebutuhan ruang kerja terhadap responden.

3. Melakukan dokumentasi pengamatan lapangan pada sebelas co-working space di Bandung.

4. Menganalisis data-data yang didapatkan dengan hasil berupa data numerik pada tabel atau grafik.

5. Menginterprestasikan dan menelaah data hasil analisis sehingga diperoleh kesimpulan.

\section{Hasil / Temuan}

\subsection{Sektor Kreatif Dominan}

Untuk mengetahui sektor apa saja yang dominan terkait dengan startup kreatif dilakukan proses survey dengan mengamati keadaan di lapangan dan membagikan kuesioner ke sebelas co-working space di Bandung yaitu BCH, BDV, Co \& Co space, Co \& Co Workspace, Dilo, Eduplex, LoKaSi, Part C, PostCard, Ruangreka, Work@. Didapatkan data-data persentase subsektor kreatif dominan di Bandung berdasarkan hasil kuesioner pengguna co-working space sebagai berikut.

Tabel 3. Sektor Kreatif Dominan di Bandung Berdasarkan Pengguna Co-working Space

\begin{tabular}{|c|c|c|c|c|c|c|c|c|c|c|c|c|}
\hline No & Sub Sektor & ВCH & BDV & $\begin{array}{c}\text { Co \& } \\
\text { Co } \\
\end{array}$ & $\begin{array}{l}\text { DI } \\
\text { LO }\end{array}$ & $\begin{array}{l}\text { Edu- } \\
\text { plex }\end{array}$ & $\begin{array}{c}\text { LoKa } \\
\text {-Si } \\
\end{array}$ & $\begin{array}{c}\text { Part } \\
\text { C }\end{array}$ & $\begin{array}{l}\text { Post } \\
\text { Card }\end{array}$ & $\begin{array}{c}\text { Ruang } \\
\text { Reka }\end{array}$ & $\begin{array}{c}\text { Work } \\
@ \\
\end{array}$ & TOTAL \\
\hline 1 & Kuliner & & & & 1 & 2 & & & 1 & & & 4 \\
\hline 2 & Fashion & 1 & 1 & & 1 & 1 & 2 & & & & & 5 \\
\hline 3 & Kriya & & & & & & & & & & & \\
\hline 4 & TV \& Radio & & & & & 1 & & & & & & 1 \\
\hline 5 & Penerbitan & 1 & 1 & & & & & & & & & 1 \\
\hline 6 & Arsitektur & & & & & 1 & & & & & & 1 \\
\hline 7 & Games & & 2 & & 3 & 4 & & & & & & 9 \\
\hline 8 & Periklanan & & 3 & & 1 & & 2 & 1 & & & & 7 \\
\hline 9 & Musik & & 1 & & & & & & & & & 2 \\
\hline 10 & Fotografi & & & & & 1 & & & & & & 3 \\
\hline 11 & Pertunjukan & & 1 & & & & & & & & & 1 \\
\hline 12 & $\begin{array}{l}\text { Desain } \\
\text { Produk }\end{array}$ & & & & & & 1 & & & & & 2 \\
\hline 13 & Seni Rupa & & & & & & & & & & & \\
\hline 14 & $\begin{array}{l}\text { Desain } \\
\text { Interior }\end{array}$ & & & & & 5 & 2 & 1 & & & & 8 \\
\hline 15 & Film & & & & 2 & 2 & 1 & & 1 & & & 6 \\
\hline 16 & DKV & 2 & 6 & 1 & 2 & 3 & 3 & & & 1 & 1 & 20 \\
\hline
\end{tabular}

Sumber: Data Pribadi (2018)

Dari tabel di atas dapat terlihat bahwa sektor ekonomi kreatif yang mendominasi di kota Bandung adalah sektor desain komunikasi visual, aplikasi pengembangan permainan, desain interior, periklanan, film animasi dan video.

\subsection{Aktivitas dan Kebutuhan}

Kelima sektor tersebut memiliki jenis aktivitas dan kebutuhan ruang kerja yang bermacammacam. Oleh karena itu, dilakukan pengelompokan terhadap aktivitas dan kebutuhan ruang 
kerja dari masing-masing sektor dominan di Bandung, yang ditampilkan dalam tabel sebagai berikut:

Tabel 4. Aktivitas dan Fasilitas Ruang Pengguna

\begin{tabular}{|c|c|c|c|c|c|c|}
\hline \multirow{2}{*}{ No } & \multirow{2}{*}{ Kebutuhan } & \multicolumn{5}{|c|}{ Sektor Dominan } \\
\hline & & DKV & Game & Desain Interior & Periklanan & Film \\
\hline $\mathbf{A}$ & \multicolumn{6}{|c|}{ Berdasar Aktivitas } \\
\hline 1 & Briefing & $\sqrt{ }$ & $\sqrt{ }$ & $\sqrt{ }$ & $\sqrt{ }$ & $\sqrt{ }$ \\
\hline 2 & Brainstorming & $\sqrt{ }$ & $\sqrt{ }$ & $\sqrt{ }$ & $\sqrt{ }$ & $\sqrt{ }$ \\
\hline 3 & Designung & $\sqrt{ }$ & $\sqrt{ }$ & $\sqrt{ }$ & $\sqrt{ }$ & $\sqrt{ }$ \\
\hline 4 & Rendering/Produksi & $\sqrt{ }$ & $\sqrt{ }$ & $\sqrt{ }$ & $\sqrt{ }$ & $\sqrt{ }$ \\
\hline $\mathbf{B}$ & \multicolumn{6}{|c|}{ Berdasar Kebutuhan Ruang } \\
\hline 1 & Meeting Room & $\Delta$ & $\Delta$ & $\Delta$ & $\Delta$ & $\Delta$ \\
\hline 2 & Idea Room & $\Delta$ & $\Delta$ & $\Delta$ & $\Delta$ & $\Delta$ \\
\hline 3 & Co-working Space & $\Delta$ & $\Delta$ & $\Delta$ & $\Delta$ & $\Delta$ \\
\hline 4 & Private Office & $\Delta$ & $\Delta$ & $\Delta$ & $\Delta$ & $\Delta$ \\
\hline 5 & Print Room & $\Delta$ & & $\Delta$ & & \\
\hline 6 & Studio Game & & $\Delta$ & & & \\
\hline 7 & Studio Set & & & & $\Delta$ & $\Delta$ \\
\hline 8 & Screening Space & & & & & $\Delta$ \\
\hline
\end{tabular}

Sumber: Data Pribadi (2018)

Dari data dan hasil observasi terhadap pengguna startup kreatif terkait dengan aktivitas dan kebutuhan ruang, serta hasil observasi terhadap ruang yang digunakan oleh para pelaku startup yang terkait dengan karakteristik desain, maka ruang yang sangat diperlukan bagi startup kreatif berdasarkan lima sektor dominan adalah co-working space.

\subsection{Penilaian Kelengkapan Fasilitas dan Komunitas Co-working Space}

Berdasarkan hasil penelitian yang dilakukan sejak Januari hingga Agustus 2018 maka didapatkan hasil sebagai berikut (lihat Tabel 5.).

Hasil yang menarik didapatkan bahwa delapan co-working space memiliki nilai fasilitas fisik yang lebih tinggi dibandingkan dengan faktor komunitasnya. Sedangkan dua co-working space memiliki poin yang sama antara faktor fisik dan non fisiknya.

Dua co-working space dengan penilai tertinggi berasal dari penyedia jasa yang sama, Co \& Co. Secara keseluruhan Co \& Co Workshare memiliki jumlah poin tertinggi dengan $87 \%$. Posisi kedua disusul dengan Co\&Co Space dengan 77\%. Bila ditelaah lebih lanjut, keduanya berbagi poin yang sama dari segi kualitas atribut dan elemen fasilitasnya (81\%), tetapi Co\&Co Workshare memiliki poin lebih dari sisi kerjasama yang dimilikinya. Tingginya poin penilaian kedua tempat ini sejalan dengan hasil yang di dapat saat melakukan observasi. Co \& Co relatif dalam keadaan ramai bila dibandingkan dengan co-working space lain pada umumnya. 


\subsubsection{Kualitas dan Kapasitas Networking dari Coworking Space}

Jumlah fasilitas yang banyak tidak menjamin sebuah co-working space menjadi tujuan para penggunanya. Seperti namanya, faktor komunitas menjadi penentu sebuah co-working space ramai dikunjungi atau tidak. Hal ini ditemukan seperti di DiLo dan Par-C (lihat tabel 5.1), meskipun fasilitas yang dimiliki tergolong lengkap untuk orang bekerja secara umum, tetapi minimnya daya tarik dari segi komunitas, menjadi pertimbangan tersendiri pengguna yang datang. Co-working space dari Co\&Co, dinilai sukses dalam tiga hal untuk menjaring orangorang untuk memakai tempatnya sebagai tempat bekerja.

Pertama, Co\&Co memiliki variasi pilihan ruang dan tempat untuk orang-orang bekerja. Tidak hanya area kerja bersama, tetapi juga ruang-ruang sewa yang dapat digunakan oleh komunitas-komunitas tertentu untuk mengadakan acara/ kegiatan. Ada faktor dimana orang-orang mempertimbangkan siapa dan apa hasil yang bisa mereka berikan dan mereka dapat dari interaksi dan bekerja bersama dengan orang lain. Faktor ini memberi efek bola salju bagi Co\&Co untuk menjaring orang-orang baru.

Kedua, penting bagi penyedia jasa co-working space untuk menjadi relevan dengan kebutuhan pengguna. Seberapa mudah tempat ini 'dijangkau' oleh para pengguna baru. Seberapa sering frekuensi sebuah komunitas memakai tempatnya untuk bekerja. Co-working space punya peran penting untuk mempertemukan para freelancer dengan para profesional melalui kegiatan workshop, pelatihan maupun kegiatan lain. Dengan adanya kegiatan semacam itu, Co\&Co menjaga agar co-working spacenya benar-benar membangun jaringan komunitas di antara penggunanya. Hal ini sejalan dengan temuan van de Koevering (2015) bahwa value ini yang lebih menjamin keberlangsungan sebuah co-working space.

Ketiga, Co\&Co, Ruangreka, dan Eduplex memiliki penawaran program dan biaya yang relatif murah bila dibandingkan dengan fasilitas yang disediakan. Upaya ketiganya untuk relavan dengan kebutuhan pasar membuka peluang untuk menjaring pengguna yang lebih luas. Para pengguna dapat menyesuaikan kebutuhannya sesuai dengan kemampuan dananya. 
Tabel 5. Rekapitulasi Hasil Survey Coworking Space di Bandung

\begin{tabular}{|c|c|c|c|c|c|c|c|c|c|c|c|}
\hline & & BDV & $\begin{array}{l}\text { Co\&Co } \\
\text { Space } \\
\end{array}$ & $\begin{array}{c}\text { Co\&Co } \\
\text { Workshare }\end{array}$ & DiLO & Eduplex & Lo.Ka.Si & Parc-C & Postcard & Ruangreka & Work@ \\
\hline \multicolumn{2}{|l|}{ Lokasi } & $\begin{array}{c}\text { Jl. } \\
\text { Gegerkalon } \\
\text { g Hilir }\end{array}$ & $\begin{array}{c}\text { Jl. } \\
\text { Dipatiukur }\end{array}$ & $\begin{array}{c}\text { Jl. } \\
\text { Cipaganti }\end{array}$ & J1. Banda & $\begin{array}{l}\text { J1. Ir. H. } \\
\text { Djuanda }\end{array}$ & $\begin{array}{l}\text { J1. Ir. H. } \\
\text { Djuanda }\end{array}$ & $\begin{array}{l}\text { Jl. Kidang } \\
\text { Pananjung }\end{array}$ & $\begin{array}{c}\text { Jl. } \\
\text { Supratman }\end{array}$ & $\begin{array}{l}\text { Jl. Raden } \\
\text { Patah }\end{array}$ & $\begin{array}{l}\text { J1. Tubagus } \\
\text { Ismail }\end{array}$ \\
\hline \multicolumn{2}{|l|}{ Mobilitas } & $\begin{array}{l}\text { Transportasi } \\
\text { Publik }\end{array}$ & $\begin{array}{l}\text { Transportas } \\
\text { i Publik }\end{array}$ & $\begin{array}{l}\text { Transportas } \\
\text { i Publik }\end{array}$ & $\begin{array}{l}\text { Transportas } \\
\text { i Publik }\end{array}$ & $\begin{array}{l}\text { Transportas } \\
\text { i Publik }\end{array}$ & $\begin{array}{l}\text { Transportas } \\
\text { i Publik }\end{array}$ & $\begin{array}{l}\text { Transportas } \\
\text { i Online }\end{array}$ & $\begin{array}{l}\text { Transportas } \\
\text { i Publik }\end{array}$ & $\begin{array}{l}\text { Transportas } \\
\text { i Online }\end{array}$ & $\begin{array}{l}\text { Transportas } \\
\text { i Online }\end{array}$ \\
\hline \multicolumn{2}{|l|}{ Tipe lokasi } & $\begin{array}{c}\text { Bandung } \\
\text { Utara }\end{array}$ & $\begin{array}{l}\text { Bandung } \\
\text { Utara }\end{array}$ & $\begin{array}{l}\text { Bandung } \\
\text { Utara }\end{array}$ & $\begin{array}{l}\text { Bandung } \\
\text { Tengah }\end{array}$ & $\begin{array}{l}\text { Bandung } \\
\text { Utara }\end{array}$ & $\begin{array}{l}\text { Bandung } \\
\text { Utara }\end{array}$ & $\begin{array}{c}\text { Bandung } \\
\text { Utara }\end{array}$ & $\begin{array}{l}\text { Bandung } \\
\text { Tengah }\end{array}$ & $\begin{array}{l}\text { Bandung } \\
\text { Utara }\end{array}$ & $\begin{array}{l}\text { Bandung } \\
\text { Utara }\end{array}$ \\
\hline \multicolumn{12}{|c|}{ Elemen eksterior dan Pembagian Ruang } \\
\hline \multicolumn{2}{|c|}{ Bentuk arsitektur } & $\begin{array}{c}\text { Gedung } \\
\text { bertingkat }\end{array}$ & Rumah & Rumah & $\begin{array}{c}\text { Gedung } \\
\text { bertingkat }\end{array}$ & Rumah & Ruko & Ruko & Rumah & Rumah & Rumah \\
\hline \multicolumn{2}{|c|}{$\begin{array}{l}\text { Tata letak ruang dan } \\
\text { pembagian ruang }\end{array}$} & & & & & $\mathrm{v}$ & & & & & \\
\hline \multirow{2}{*}{$\begin{array}{l}\text { Pencahayaa } \\
\mathrm{n}\end{array}$} & Alami & $\mathrm{V}$ & $\mathrm{V}$ & $\mathrm{v}$ & & $\mathrm{V}$ & $\mathrm{V}$ & & $\mathrm{V}$ & & \\
\hline & Buatan & $\mathrm{v}$ & $\mathrm{v}$ & $\mathrm{v}$ & $\mathrm{v}$ & $\mathrm{v}$ & $\mathrm{v}$ & $\mathrm{V}$ & $\mathrm{V}$ & $\mathrm{v}$ & $\mathrm{v}$ \\
\hline \multicolumn{12}{|c|}{ Office Decor } \\
\hline \multicolumn{2}{|c|}{ Tampilan estetika } & $\mathrm{v}$ & $\mathrm{v}$ & $\mathrm{V}$ & & $\mathrm{V}$ & & & $\mathrm{V}$ & $\mathrm{V}$ & \\
\hline \multicolumn{2}{|c|}{$\begin{array}{lll}\text { Tampilan ruang } & \text { dan } \\
\text { implementasi branding } & \\
\end{array}$} & $\mathrm{v}$ & $\mathrm{v}$ & $\mathrm{v}$ & & $\mathrm{v}$ & $\mathrm{v}$ & $\mathrm{v}$ & $\mathrm{V}$ & $\mathrm{V}$ & \\
\hline \multirow{3}{*}{$\begin{array}{l}\text { Variasi area } \\
\text { kerja/ ruang }\end{array}$} & $\begin{array}{l}\text { Area Kerja } \\
\text { Individu }\end{array}$ & & $\mathrm{v}$ & $\mathrm{v}$ & & & & & & & \\
\hline & $\begin{array}{l}\text { Area Kerja } \\
\text { Grup (saling } \\
\text { kenal) }\end{array}$ & $\mathrm{V}$ & $\mathrm{V}$ & $\mathrm{v}$ & $\mathrm{v}$ & $\mathrm{v}$ & $\mathrm{v}$ & $\mathrm{v}$ & $\mathrm{V}$ & $\mathrm{v}$ & $\mathrm{v}$ \\
\hline & $\begin{array}{l}\text { Area Kerja } \\
\text { Bersama } \\
\text { (tidak saling } \\
\text { kenal) }\end{array}$ & $\mathrm{v}$ & $\mathrm{v}$ & $\mathrm{v}$ & $\mathrm{v}$ & $\mathrm{v}$ & $\mathrm{v}$ & $\mathrm{v}$ & $\mathrm{V}$ & $\mathrm{v}$ & $\mathrm{v}$ \\
\hline \multicolumn{12}{|c|}{ Facilities and Services } \\
\hline \multicolumn{2}{|c|}{$\begin{array}{l}\text { Booking system for spaces } \\
\text { and workpots }\end{array}$} & & $\mathrm{v}$ & $\mathrm{v}$ & $\mathrm{v}$ & $\mathrm{v}$ & $\mathrm{v}$ & $\mathrm{v}$ & $\mathrm{V}$ & $\mathrm{v}$ & $\mathrm{v}$ \\
\hline \multicolumn{2}{|c|}{ Canteen/restaurant } & $\mathrm{V}$ & $\mathrm{V}$ & $\mathrm{V}$ & $\mathrm{v}$ & $\mathrm{v}$ & $\mathrm{V}$ & $\mathrm{V}$ & $\mathrm{V}$ & & \\
\hline \multicolumn{2}{|c|}{ Cleaning services } & $\mathrm{V}$ & $\mathrm{V}$ & $\mathrm{V}$ & $\mathrm{v}$ & $\mathrm{v}$ & $\mathrm{v}$ & $\mathrm{v}$ & $\mathrm{V}$ & $\mathrm{v}$ & $\mathrm{V}$ \\
\hline \multicolumn{2}{|c|}{ Clothing services } & & $\mathrm{v}$ & $\mathrm{v}$ & & & & & & & \\
\hline
\end{tabular}




\begin{tabular}{|c|c|c|c|c|c|c|c|c|c|c|}
\hline $\begin{array}{l}\text { Coffee and tea vending } \\
\text { machine }\end{array}$ & $\mathrm{v}$ & $\mathrm{v}$ & $\mathrm{v}$ & $\mathrm{v}$ & & & & & $\mathrm{v}$ & $\mathrm{v}$ \\
\hline $\begin{array}{l}\text { Coworking host (stimulates } \\
\text { interaction) }\end{array}$ & $\mathrm{v}$ & $\mathrm{v}$ & & & $\mathrm{v}$ & & $\mathrm{v}$ & & $\mathrm{v}$ & \\
\hline $\begin{array}{l}\text { Opening hours (24 hours } \\
\text { access) }\end{array}$ & $08.00-17.00$ & $08.00-21.00$ & $08.00-21.00$ & $09.00-20.00$ & 24 hours & $08.00-23.00$ & $09.00-21.30$ & $09.00-21.00$ & $09.00-21.00$ & $08.00-19.00$ \\
\hline Receptions and helpdesk & $\mathrm{V}$ & & $\mathrm{V}$ & & & & & & $\mathrm{V}$ & $\mathrm{V}$ \\
\hline \multicolumn{11}{|c|}{ Collaboration and openness } \\
\hline Collaborative spaces & $\mathrm{v}$ & $\mathrm{v}$ & $\mathrm{v}$ & $\mathrm{V}$ & $\mathrm{V}$ & $\mathrm{v}$ & $\mathrm{V}$ & $\mathrm{V}$ & $\mathrm{v}$ & $\mathrm{v}$ \\
\hline Conference rooms & $\mathrm{V}$ & $\mathrm{v}$ & $\mathrm{v}$ & $\mathrm{v}$ & $\mathrm{v}$ & & & $\mathrm{V}$ & $\mathrm{V}$ & $\mathrm{v}$ \\
\hline Event space & $\mathrm{v}$ & $\mathrm{v}$ & $\mathrm{v}$ & & $\mathrm{v}$ & $\mathrm{v}$ & & V & $\mathrm{v}$ & $\mathrm{v}$ \\
\hline \multicolumn{11}{|l|}{ Fitness centre } \\
\hline $\begin{array}{l}\text { Informal areas with sofas } \\
\text { and couches }\end{array}$ & $\mathrm{v}$ & $\mathrm{v}$ & $\mathrm{v}$ & & $\mathrm{v}$ & & & & $\mathrm{v}$ & $\mathrm{v}$ \\
\hline Kitchen areas & & $\mathrm{v}$ & $\mathrm{v}$ & & & & & & & \\
\hline Quite spaces & & & $\mathrm{V}$ & & & & & & & \\
\hline \multicolumn{11}{|c|}{ Community and Sustainability } \\
\hline Customized social network & $\begin{array}{c}\text { Website } \\
\text { Facebook } \\
\text { Youtube } \\
\text { Twitter } \\
\text { Instagram }\end{array}$ & $\begin{array}{l}\text { Website } \\
\text { Youtube } \\
\text { Twitter }\end{array}$ & $\begin{array}{l}\text { Website } \\
\text { Youtube } \\
\text { Twitter }\end{array}$ & Website & $\begin{array}{l}\text { Website } \\
\text { Facebook } \\
\text { Twitter } \\
\text { Instagram }\end{array}$ & $\begin{array}{l}\text { Website } \\
\text { Instagram }\end{array}$ & Website & & $\begin{array}{l}\text { Website } \\
\text { Facebook } \\
\text { Twitter } \\
\text { Instagram }\end{array}$ & $\begin{array}{l}\text { Website } \\
\text { Facebook } \\
\text { Twitter }\end{array}$ \\
\hline Ecological sustinable & & $\mathrm{v}$ & $\mathrm{v}$ & & & & & & & \\
\hline $\begin{array}{l}\text { Network } \\
\text { events/training/workshops }\end{array}$ & $\mathrm{v}$ & $\mathrm{v}$ & $\mathrm{v}$ & & $\mathrm{v}$ & $\mathrm{v}$ & & $\mathrm{V}$ & $\mathrm{v}$ & $\mathrm{v}$ \\
\hline Organizational sustainable & & $\mathrm{V}$ & $\mathrm{v}$ & & & & & & & \\
\hline $\begin{array}{ll}\text { Virtual } & \text { organization } \\
\text { platform } & \end{array}$ & $\mathrm{v}$ & & $\mathrm{v}$ & & $\mathrm{v}$ & & & & & \\
\hline Social events & $\mathrm{v}$ & $\mathrm{V}$ & $\mathrm{v}$ & & $\mathrm{v}$ & $\mathrm{v}$ & & $\mathrm{V}$ & $\mathrm{v}$ & $\mathrm{v}$ \\
\hline Presentation or readings & & & $\mathrm{V}$ & & & & & & & \\
\hline \multicolumn{11}{|c|}{ Accessibility } \\
\hline Diversity of the tenants & & $\mathrm{v}$ & $\mathrm{v}$ & $\mathrm{v}$ & & & $\mathrm{v}$ & $\mathrm{V}$ & $\mathrm{v}$ & $\mathrm{v}$ \\
\hline $\begin{array}{l}\text { Lease contract (price, } \\
\text { period, accessibility of) }\end{array}$ & Free & $\begin{array}{c}50 \mathrm{k} / 3 \mathrm{hr} \\
100 \mathrm{k} / 1 \text { day } \\
300 \mathrm{k} / 1 \text { week } \\
650-\end{array}$ & $\begin{array}{c}50 \mathrm{k} / 3 \mathrm{hr} \\
100 \mathrm{k} / 1 \text { day } \\
300 \mathrm{k} / 1 \text { week } \\
650-\end{array}$ & Free & $\begin{array}{c}60 \mathrm{k} / 3 \mathrm{hr} \\
100 \mathrm{k} / 1 \text { day } \\
400 \mathrm{k} / 1 \text { week } \\
1.2 \mathrm{~m} / 1 \mathrm{mth}\end{array}$ & $400 \mathrm{k} / 3 \mathrm{hr}$ & & & $\begin{array}{c}75 \mathrm{k} / 1 \text { day } \\
30 \mathrm{k} / 1 \text { week } \\
500- \\
950 \mathrm{k} / 1 \mathrm{mth}\end{array}$ & $\begin{array}{c}50 \mathrm{k} / 1 \mathrm{day} \\
500 \mathrm{k} / 1 \mathrm{mth}\end{array}$ \\
\hline
\end{tabular}


Jurnal
Vol.3 No.1, April 2018
ISSN Cetak 2477 - 0566
ISSN Elektronik 2615 - 677

Jurnal
Vol.3 No.1, April 2018
ISSN Cetak 2477 - 0566
ISSN Elektronik 2615 - 677

\begin{tabular}{|c|c|c|c|c|c|c|c|c|c|c|}
\hline & & $950 \mathrm{k} / 1 \mathrm{mth}$ & $950 \mathrm{k} / 1 \mathrm{mth}$ & & & & & & & \\
\hline Total & $18(60 \%)$ & $23(77 \%)$ & $26(87 \%)$ & $10(33 \%)$ & $18(60 \%)$ & $12(40 \%)$ & $10(33 \%)$ & $15(50 \%)$ & $17(57 \%)$ & $14(47 \%)$ \\
\hline Fasilitas & $10(63 \%)$ & $13(81 \%)$ & $13(81 \%)$ & $7(44 \%)$ & $11(69 \%)$ & $8(50 \%)$ & $8(50 \%)$ & $8(50 \%)$ & $10(63 \%)$ & $7(44 \%)$ \\
\hline Komunitas & $8(57 \%)$ & $10(71 \%)$ & $13(93 \%)$ & $3(21 \%)$ & $7(50 \%)$ & $4(29 \%)$ & $2(14 \%)$ & $7(50 \%)$ & $7(50 \%)$ & $7(50 \%)$ \\
\hline
\end{tabular}

Sumber: Data Pribadi (2018) 


\section{Kesimpulan}

Berdasarkan proses penelitian yang telah dilaksanakan, maka kesimpulan yang didapat antara lain :

1. Para pengguna coworking space di kota Bandung, khususnya para startup di bidang industri kreatif, yang didominasi oleh kalangan milenial dari sektor desain komunikasi visual, aplikasi pengembangan permainan, desain interior, periklanan, film animasi dan video memerlukan tempat kerja yang berbeda dengan suasana 'kantor' pada umumnya. Para pengguna cenderung bekerja pada tempat co-working space karena lebih memilih untuk bekerja dengan cara baru dibandingkan pekerjaan kantoran pada umumnya. Hal yang menjadi pertimbangan pemilihan coworking space antara lain waktu kerja yang fleksibel, juga faktor komunitas.

2. Besarnya daya tarik sebuah co-working space bagi para pengguna di bidang industri kreatif, diperlukan adanya kombinasi serta perpaduan antara kelengkapan fasilitas-fasilitas yang disediakan oleh penyedia jasa dan juga value komunitas yang dapat ditawarkan oleh co-working space kepada penyewa. Meskipun kelengkapan fasilitas menjadi faktor terpenting, tetapi hal ini perlu didukung dengan nilai jual co-working space melalui jejaring yang dimilikinya. Jejaring ini memiliki value yang tinggi untuk menarik minat penyewa. Hal ini tidak hanya memberi kepastian keberlangsungan operasional bagi pemilik tempat tetapi juga menjadi fasilitator bagi pertemuan antar sesama freelancer dan antara freelancer dengan para pemberi kerja.

\section{Daftar Pustaka}

[1] Amirulloh Syarbini, Buku Pintar Pendidikan Karakter, (Jakarta: as@ prima pustaka, 2012), cet. I, hlm. 13.

[2] Bilandzic, M., \& Foth, M. (2013). Libraries as coworking spaces: Understanding user motivations and perceived barriers to social learning. Library Hi Tech, 31(2), 254-273. https://doi.org/10.1108/07378831311329040

[3] Blank, S. (2014). What's A Startup? First Principles. Nature Reviews Drug Discovery, 13(8), 570-570.

[4] Forbes. (2015). 90\% Of Startups Fail: Here's What You Need To Know About The $10 \%$.

[5] Jakonen, M., Kivinen, N., Salovaara, P., \& Hirkman, P. (2017). Towards an Economy of Encounters? A critical study of a ff ectual assemblages in coworking. Scandinavian Journal of Management, 33(4), 235-242. https://doi.org/10.1016/j.scaman.2017.10.003.

[6] Jaya, Mardi A., Ferdiana, R. dan Fauziati,S. (2017). Analisis Faktor Keberhasilan Startup Digital di Yogyakarta.

[7] Marcelina, A., Ardana, I., \& Yong, S. de. (2016). Perancangan Interior Creative Collaborative Space di Surabaya. Jurnal Intra, 4(2), 814-823.

[8] Martisen, Oyvind L. (2000). List of Creative People Characters. Norway: BI Norwegian Bussiness School.

[9] Merkel, J. (2015). City Research Online City, University of London Institutional Repository Coworking in the city, 15, 121-139.

[10] Metz, J., \& Archuleta, G. (n.d.). Market Feasibility Study Coworking Space.

[11] Ries, E. (2011). The lean startup: How today's entrepreneurs use continuous innovation to create radically successful businesses. New York: Crown Business.

[12] http://indonesiakreatif.bekraf.go.id 